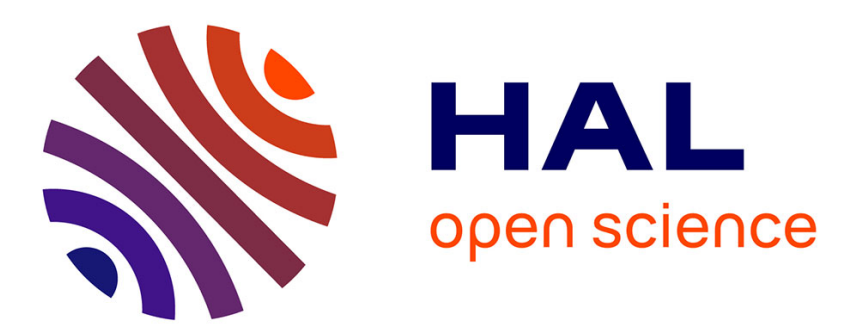

\title{
Genetic structure of Chinese Apis dorsata population based on microsatellites
}

\author{
Lian-Fei Cao, Huo-Qing Zheng, Fu-Liang Hu, H. Hepburn
}

\section{To cite this version:}

Lian-Fei Cao, Huo-Qing Zheng, Fu-Liang Hu, H. Hepburn. Genetic structure of Chinese Apis dorsata population based on microsatellites. Apidologie, 2012, 43 (6), pp.643-651. 10.1007/s13592-012-01398. hal-01003661

\section{HAL Id: hal-01003661 \\ https://hal.science/hal-01003661}

Submitted on 1 Jan 2012

HAL is a multi-disciplinary open access archive for the deposit and dissemination of scientific research documents, whether they are published or not. The documents may come from teaching and research institutions in France or abroad, or from public or private research centers.
L'archive ouverte pluridisciplinaire HAL, est destinée au dépôt et à la diffusion de documents scientifiques de niveau recherche, publiés ou non, émanant des établissements d'enseignement et de recherche français ou étrangers, des laboratoires publics ou privés. 


\title{
Genetic structure of Chinese Apis dorsata population based on microsatellites
}

\author{
Lian-Fei $\mathrm{CAO}^{1}$, Huo-Qing Zheng ${ }^{1}$, Fu-Liang $\mathrm{HU}^{1}$, H. R. HePBuRN ${ }^{2}$ \\ ${ }^{1}$ College of Animal Sciences, Zhejiang University, 866 Yuhangtang Road, Hangzhou 310058, China \\ ${ }^{2}$ Department of Zoology and Entomology, Rhodes University, Grahamstown, South Africa
}

Received 24 October 2011 - Revised 26 February 2012 - Accepted 2 April 2012

\begin{abstract}
We investigated the genetic structure of Chinese Apis dorsata population based on DNA microsatellites. The results show that populations from different geographical regions are significantly differentiated. Furthermore, the A. dorsata population from Hainan Island very probably diverged from that of the China mainland and also exhibits a lower level of genetic diversity, which is probably the result of founder effects and genetic drift. The results provide useful information for effective management and conservation of A. dorsata in China, particularly with regard to the population of Hainan Island.
\end{abstract}

\section{Apis dorsata / genetic structure / China / microsatellites}

\section{INTRODUCTION}

Apis dorsata Fabricius, the common giant honeybee, is found throughout South and Southeast Asia (Oldroyd and Wongsiri 2006; Hepburn and Radloff 2011). A. dorsata plays an important role as a pollinator of tropical rainforest and various crops (Wongsiri et al. 2001; Corlett 2011; Partap 2011). Most honey (70$80 \%$ ) produced in Nepal, India, and some other Southeast Asian countries originate from the giant honeybees (Woyke et al. 2008). Honey harvested from $A$. dorsata nests also provides an important source of income for people in remote mountain areas. However, many threats are severely affecting this important native species, the main ones being deforestation, hunting with destructive methods, and the loss of nest sites (Oldroyd and Wongsiri 2006; Oldroyd and Nanork 2009). Nath et al. (1994)

Corresponding author: F. Hu,

flhu@zju.edu.cn

Manuscript editor: Marina Meixner reported a decrease in the number of colonies of A. dorsata in Tamil Nadu, India. Our own experiences also suggest that the number of $A$. dorsata colonies in China has declined, and in some regions, A. dorsata is on the verge of disappearing. For the conservation of $A$. dorsata, some strategies such as sustainable hunting based on harvesting in a more sustainable manner have been proposed (Oldroyd and Wongsiri 2006; Oldroyd and Nanork 2009).

Knowledge of genetic population structure can be of great use in the construction of natural resource management and conservation programs for $A$. dorsata, especially considering its wide distribution and great variation. A. dorsata can be classified into three subspecies (Apis dorsata dorsata, Apis dorsata binghami, and Apis dorsata breviligula) (Ruttner 1988; Oldroyd and Wongsiri 2006), and more recently, A. breviligula species was suggested by Lo et al. (2010). Furthermore, an extensive sequence divergence has been found between $A$. dorsata dorsata samples from the Indian subcontinent and other mainland populations (Smith 1991; Arias and 
Sheppard 2005). However, the genetic relationship among $A$. dorsata subspecies has not been clarified, and the genetic divergence within $A$. dorsata across its range is little known. In China, A. dorsata is mainly distributed in the south, including Yunnan and Guangxi Provinces and Hainan Island. In a previous study (unpublished data), Chinese $A$. dorsata populations were classified as $A$. dorsata dorsata based on mitochondrial DNA sequences. However, the $A$. dorsata of Hainan Island have never been included in comparative studies on the worldwide distribution of $A$. dorsata (Oldroyd and Wongsiri 2006; Hepburn and Radloff 2011). The population structure of Chinese $A$. dorsata has not been previously investigated.

Microsatellites are valuable tools for population structure studies due to their high levels of polymorphism as well as being selectively neutral and displaying codominance and Mendelian inheritance (Goldstein and Schlötterer 1999). Using microsatellites, Paar et al. (2004) showed that there was a significant population differentiation between different geographical regions of $A$. dorsata in northern Indian. Insuan et al. (2007) also found significant differentiation among A. dorsata populations from geographically different regions in Thailand using three microsatellite loci, which was not detectable by mtDNA sequences. Based on microsatellite analysis, significant genetic differentiation was observed among three sampling days in a drone congregation area of $A$. dorsata (Kraus et al. 2005). DNA microsatellites can also be used to estimate the extent of worker drifting between nests in $A$. dorsata aggregations (Paar et al. 2002). Few data on the variation of Chinese $A$. dorsata are available. To address this, we examined the population structure of Chinese $A$. dorsata using microsatellite markers.

\section{MATERIALS AND METHODS}

\subsection{Sample collection}

A. dorsata samples were collected from Yunnan, Guangxi, and Hainan provinces of China in May 2010. The localities and the number of colonies sampled are given in Figure 1. Samples from the same locality were collected randomly and not from aggregations. Specimens were placed in $95 \%$ ethanol and kept at $-20^{\circ} \mathrm{C}$.

\subsection{DNA extraction and microsatellite amplification}

DNA was extracted from the thorax of each worker bee with proteinase $\mathrm{K}$ followed by the standard phenolchloroform method (Sambrook et al. 1989). DNA was then diluted to $10 \mathrm{ng} / \mu \mathrm{L}$ with distilled water for amplification. The microsatellite loci used were A14, A88, A76, A24, and B124 (Estoup et al. 1993). These loci were amplified using the polymerase chain reaction (PCR). The reverse primers were labeled with the fluorescent dyes FAM or HEX. The PCRs were carried out in a total volume of $10 \mu \mathrm{L}$. Each reaction contained $0.4 \mu \mathrm{M}$ of each primer, $100 \mu \mathrm{M}$ of dNTP, 0.4 units of Taq polymerase, $1 \times$ reaction buffer, 1.2$1.7 \mathrm{mM}$ of $\mathrm{MgCl}_{2}$, and $1 \mu \mathrm{L}$ of sample DNA. PCRs profiles consisted of 1 cycle at $94^{\circ} \mathrm{C}$ for $4 \mathrm{~min}$; 35 cycles of $94^{\circ} \mathrm{C}$ for $30 \mathrm{~s}, 55-58^{\circ} \mathrm{C}$ for $30 \mathrm{~s}$, and $72^{\circ}$ $\mathrm{C}$ for $30 \mathrm{~s}$; and 1 cycle at $72^{\circ} \mathrm{C}$ for $10 \mathrm{~min}$. The PCR products were visualized on an $\mathrm{ABI} 3730 \mathrm{XL}$ automated sequencer (Applied Biosystems, Foster City, CA). Genotypes were scored using GeneMarker software (Softgenetics, State College, PA).

\subsection{Data analysis}

Because workers within social insect colonies are typically related and should not be considered independent of each other in population analyses, we followed the methods of Paar et al. (2004) and Berghoff et al. (2008). Twenty-four workers per colony were subjected to microsatellite analysis. The genotypes of the mother queen were derived from the genotypes of the sampled workers for each colony using the program MATESOFT 1.0 (Moilanen et al. 2004), according to Kronauer et al. (2006). After the genotypes of the mother queens were determined, the genotypes of each worker's father were derived by subtracting the queen allele of each worker (Oldroyd et al. 1996). The male genotypes were then diploidized and for the following analyses. For the male genotypes that could not be determined exactly, alternative male genotypes were entered as heterozygote for analyses. 


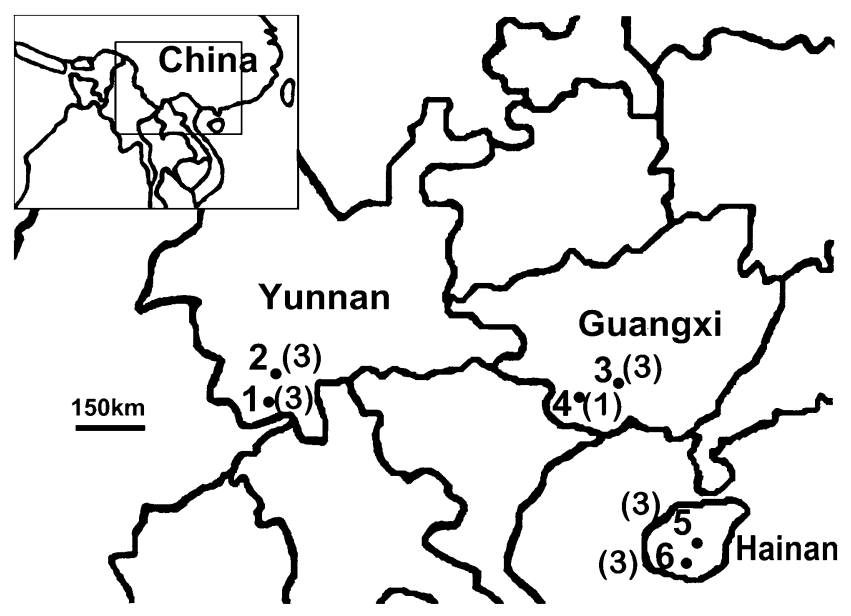

Figure 1. Collection sites and number of $A$. dorsata in China. Symbols indicate localities from which samples were collected. The number of colonies collected is given in bracket. 1 Xishuangbanna, $700 \mathrm{~m}$ (altitude), $21^{\circ}$ $50^{\prime} \mathrm{N}, 101^{\circ} 10^{\prime} \mathrm{E}$; 2 Puer, $1,300 \mathrm{~m}, 22^{\circ} 53^{\prime} \mathrm{N}, 100^{\circ} 10^{\prime} \mathrm{E}$; 3 Nanning, $100 \mathrm{~m}, 22^{\circ} 40^{\prime} \mathrm{N}, 108^{\circ} 20^{\prime} \mathrm{E}$; 4 Chongzuo, $500 \mathrm{~m}, 22^{\circ} 30^{\prime} \mathrm{N}, 107^{\circ} 20^{\prime} \mathrm{E}$; 5 Qiongzhong, $300 \mathrm{~m}, 1^{\circ} 16^{\prime} \mathrm{N}, 109^{\circ} 47^{\prime} \mathrm{E}$; 6 Baoting, $100 \mathrm{~m}, 18^{\circ} 30^{\prime} \mathrm{N}, 109^{\circ} 40^{\prime} \mathrm{E}$.

Three A. dorsata populations (Yunnan, Guangxi, and Hainan) were defined in our study according to geographical regions. Exact tests for Hardy-Weinberg equilibrium were conducted for each locuspopulation combination (Paar et al. 2004), and genotypic linkage disequilibrium for all pairs of loci in each population. Analyses were carried out with the mother queen genotypes using the software package GENEPOP 4.1 (Rousset 2008). The overall A. dorsata population was also tested.

Allelic richness $(A)$ and private allelic richness (pA) were calculated with the diploidized male genotypes and corrected for differences in sample size using the rarefaction method (Kalinowski 2004) for each locuspopulation combination in the program HP-Rare (Kalinowski 2005). Nei's (1987) unbiased estimates of expected heterozygosities $(H \mathrm{~s})$ were estimated with the program FSTAT 2.9.3 (Goudet 2001). Because workers in social insect colonies are related, $H$ s would be biased when estimated from the worker genotypes. Unequal sampling of spermatozoa during fertilization may also influence the allele frequency. The differences in allele frequencies between the sexes in the parental generation (Berghoff et al. 2008) were tested by calculating pairwise $F_{\mathrm{ST}}$ for each population in FSTAT 2.9.3.

For examining population structure of $A$. dorsata in China, the unbiased multilocus estimate of $F_{\mathrm{ST}}$
(Weir and Cockerham 1984) was calculated for overall population and population pairs across loci based on the derived male genotypes with Program FSTAT 2.9.3 (Goudet 2001). The $F_{\text {ST }}$ estimates were tested for significant differences from zero by permuting multilocus genotypes among samples. Allele frequency differences (genic differentiation) for population pairs were also tested with GENEPOP 4.1 (Rousset 2008) using the derived male genotypes. The genetic differentiation between Hainan Island and China mainland was also analyzed. Further, an analysis of molecular variance (AMOVA) was carried out to analyze the variation within and between populations. The AMOVA analysis and significance tests are performed using GenAlEx version 6.4 (Peakall and Smouse 2006).

Allele frequencies were used to generate the $D_{A}$ genetic distance (Nei et al. 1983) between each pair of colonies, and distance matrices were used to build phylogenetic trees using the unweighted pair group method with arithmetic mean (UPGMA) and neighbor-joining (NJ) algorithms with the DISPAN program (Ota 1993). The robustness of the phylogenetic relationships was assessed using bootstrap analysis with 1,000 replications. Principal component analysis (PCA) was also performed using GenAlEx version 6.4 to plot the genetic distance between individual colonies. 
To assess whether the Hainan Island A. dorsata population exhibited detectable genetic deterioration in comparison with the mainland population (Yunnan and Guangxi), the difference of $A, \mathrm{pA}$, and $H \mathrm{~s}$ between Hainan population and mainland population was tested using one-way ANOVAs.

\section{RESULTS}

The genotypes of the mother queens are shown in Table I. No population showed deviation from Hardy-Weinberg equilibrium (overall $A$. dorsata population, $\chi^{2}=4.905, P=$ 1.000; Yunnan, $\chi^{2}=2.779, P=0.986$; Guangxi, $\chi^{2}=1.222, P=1.000$; Hainan, $\chi^{2}=0.904, P=$ $0.989)$. We did not detect significant linkage disequilibrium between any pair of loci $(P>0.05$ in all cases).

For all $A$. dorsata populations in our study, the total number of alleles detected per locus ranged from 7 at locus A14 to 14 at locus A88, and average allelic richness and expected heterozygosity were $9.208 \pm 2.101$ and $0.745 \pm$ 0.097 (Table II). For each A. dorsata population, the mean number of alleles varied from 6.4
(Hainan) to 9.6 (Yunnan). Allelic richness $(A)$, expected heterozygosities $(H \mathrm{~s})$, and private allelic richness (pA) for each locus and each population are also shown in Table II. Allelic richness estimates in the three $A$. dorsata geographical populations ranged from 4.000 (A14 in Guangxi population) to 13.665 (A88 in Yunnan population). Mean allelic richness across loci were 6.266 \pm 1.127 (Hainan), 6.800 \pm 1.924 (Guangxi), and 9.461 \pm 2.509 (Yunnan). Heterozygosity estimates ranged from 0.359 (A14 in Hainan population) to 0.878 (A88 in Yunnan population). Mean heterozygosity estimates were $0.578 \pm 0.136$ (Hainan), $0.714 \pm$ 0.138 (Guangxi), and $0.786 \pm 0.072$ (Yunnan). Average private allelic richness for the three populations were $0.200 \pm 0.447$ (Guangxi), $0.203 \pm 0.452$ (Hainan), and $1.995 \pm 1.592$ (Yunnan). There was no significant genetic differentiation between parental queens and males in any of the populations by pairwise $F_{\mathrm{ST}}$ estimates $(P>0.05$ in all cases).

Population structure analysis based on $F_{\mathrm{ST}}$ showed that $A$. dorsata populations were significantly differentiated at the nuclear microsatellite loci (overall $\left.F_{\mathrm{ST}}=0.107 \pm 0.030, P=0.000\right) . \quad F_{\mathrm{ST}}$

Table I. Inferred queen genotypes of each colony at each locus.

\begin{tabular}{|c|c|c|c|c|c|c|}
\hline \multicolumn{2}{|c|}{ Colony/locus } & \multirow{2}{*}{$\frac{\text { A14 }}{207 / 211}$} & \multirow{2}{*}{$\frac{\mathrm{A} 88}{137 / 141}$} & \multirow{2}{*}{$\begin{array}{l}\text { A76 } \\
207 / 215\end{array}$} & \multirow{2}{*}{$\frac{A 24}{99 / 99}$} & \multirow{2}{*}{$\frac{\text { B124 }}{215 / 219}$} \\
\hline Yunnan & 1 & & & & & \\
\hline & 2 & $205 / 209$ & $131 / 141$ & $203 / 207$ & $99 / 101$ & $215 / 217$ \\
\hline & 3 & $205 / 207$ & $131 / 143$ & $203 / 203$ & $97 / 101$ & $215 / 217$ \\
\hline & 4 & $205 / 215$ & $129 / 135$ & $203 / 215$ & $99 / 99$ & $215 / 217$ \\
\hline & 5 & 209/209 & $129 / 139$ & $207 / 215$ & $95 / 101$ & $215 / 217$ \\
\hline & 6 & $207 / 207$ & $131 / 135$ & $203 / 203$ & $95 / 99$ & $215 / 215$ \\
\hline \multirow[t]{4}{*}{ Guangxi } & 1 & $205 / 207$ & $131 / 139$ & $203 / 213$ & 93/99 & $215 / 217$ \\
\hline & 2 & $207 / 209$ & $131 / 146$ & $207 / 217$ & $93 / 95$ & $215 / 217$ \\
\hline & 3 & $207 / 209$ & $129 / 137$ & $203 / 205$ & $99 / 101$ & $215 / 217$ \\
\hline & 4 & $205 / 207$ & $135 / 139$ & $205 / 207$ & $99 / 99$ & $215 / 215$ \\
\hline \multirow[t]{6}{*}{ Hainan } & 1 & 209/209 & $135 / 137$ & $203 / 213$ & $95 / 99$ & $223 / 223$ \\
\hline & 2 & 209/209 & $131 / 135$ & $203 / 213$ & $95 / 99$ & $223 / 223$ \\
\hline & 3 & 209/209 & $135 / 141$ & $213 / 213$ & $95 / 105$ & $223 / 223$ \\
\hline & 4 & $209 / 209$ & $135 / 139$ & $213 / 213$ & $95 / 99$ & $223 / 223$ \\
\hline & 5 & 209/209 & $135 / 135$ & $213 / 215$ & $95 / 99$ & $223 / 223$ \\
\hline & 6 & 209/209 & $135 / 135$ & $203 / 213$ & $95 / 95$ & $223 / 223$ \\
\hline
\end{tabular}


Table II. Genetic diversity of $A$. dorsata populations.

\begin{tabular}{|c|c|c|c|c|c|}
\hline Locus/subpopulation & & Yunnan (144) & Guangxi (96) & Hainan Island (144) & Total population (384) \\
\hline \multirow[t]{4}{*}{ A14 } & $N$ & 7 & 4 & 6 & 7 \\
\hline & $A$ & 6.892 & 4.000 & 5.784 & 6.344 \\
\hline & $H \mathrm{~s}$ & 0.742 & 0.539 & 0.359 & 0.591 \\
\hline & $\mathrm{pA}$ & 1.107 & 0.000 & 0.001 & \\
\hline \multirow[t]{4}{*}{ A 88} & $N$ & 14 & 9 & 5 & 14 \\
\hline & $A$ & 13.665 & 9.000 & 4.999 & 11.958 \\
\hline & $H \mathrm{~s}$ & 0.878 & 0.859 & 0.718 & 0.842 \\
\hline & $\mathrm{pA}$ & 4.667 & 0.001 & 0.000 & \\
\hline \multirow[t]{4}{*}{ A76 } & $N$ & 9 & 8 & 8 & 10 \\
\hline & $A$ & 8.890 & 8.000 & 7.888 & 9.124 \\
\hline & $H \mathrm{~s}$ & 0.837 & 0.822 & 0.658 & 0.811 \\
\hline & $\mathrm{pA}$ & 0.890 & 1.000 & 0.000 & \\
\hline \multirow[t]{4}{*}{$\mathrm{A} 24$} & $N$ & 9 & 7 & 6 & 9 \\
\hline & $A$ & 8.880 & 7.000 & 5.779 & 8.339 \\
\hline & $H \mathrm{~s}$ & 0.776 & 0.745 & 0.579 & 0.736 \\
\hline & $\mathrm{pA}$ & 1.003 & 0.000 & 0.001 & \\
\hline \multirow[t]{4}{*}{ B124 } & $N$ & 9 & 6 & 7 & 11 \\
\hline & $A$ & 8.977 & 6.000 & 6.878 & 10.275 \\
\hline & $H \mathrm{~s}$ & 0.699 & 0.603 & 0.578 & 0.745 \\
\hline & $\mathrm{pA}$ & 2.110 & 0.000 & 1.011 & \\
\hline \multirow[t]{4}{*}{ Average } & $N$ & 9.6 & 6.8 & 6.4 & 10.2 \\
\hline & $A$ & 9.461 & 6.8 & 6.266 & 9.208 \\
\hline & $H \mathrm{~s}$ & 0.786 & 0.714 & 0.578 & 0.745 \\
\hline & $\mathrm{pA}$ & 1.955 & 0.200 & 0.203 & \\
\hline
\end{tabular}

Workers used for analyses are given in bracket. Minimum sample size for $A$ and pA was 192 genes

$N$ the number of alleles, $A$ allelic richness, $H s$ expected heterozygosities, $p A$ private allelic richness

values in any pair of the $A$. dorsata populations (Yunnan, Guangxi, and Hainan) were significantly different from zero (Table III). The Hainan Island population had higher $F_{\mathrm{ST}}$ scores $(0.138$ (vs. Yunnan) and 0.150 (vs. Guangxi)) in comparison with the $F_{\mathrm{ST}}$ between Yunnan and Guangxi (0.022). Allele frequency differences (genic differentiation) in the three pairs of populations were also highly significant. The AMOVA revealed that differences between indi-

Table III. $F_{\mathrm{ST}}$ values (Weir and Cockerham 1984) among $A$. dorsata populations.

\begin{tabular}{|c|c|c|c|c|}
\hline \multicolumn{2}{|c|}{ Populations compared } & \multirow{2}{*}{$\frac{F_{\mathrm{xy}}}{0.138}$} & \multirow{2}{*}{$\frac{\text { Standard error }}{0.038}$} & \multirow{2}{*}{$\frac{P}{<0.00007}$} \\
\hline Yunnan & Hainan Island & & & \\
\hline Guangxi & Hainan Island & 0.150 & 0.050 & $<0.00007$ \\
\hline Yunnan & Guangxi & 0.022 & 0.009 & $<0.00007$ \\
\hline
\end{tabular}

Significant differences from zero are indicated by $P$ values 
viduals within populations and within-individual differences were large (74 \% and $20 \%$, respectively; $P<0.01)$, while a low but significant proportion of variation was detected among populations $(6 \% ; P<0.01)$.

Phylogenetic trees were constructed using the UPGMA and NJ algorithms for individual colonies. As both trees retained similar structure, only the NJ tree constructed from a matrix of $\mathrm{D}_{\mathrm{A}}$ distances is presented in Figure 2. The Hainan Island population was divergent from the two China mainland populations (Yunnan and Guangxi) significantly. The grouping of samples in the PCA plot (Figure 3) is consistent with the clustering pattern of the NJ tree.

Due to the clear geographic isolation and genetic structure between the Hainan Island $A$. dorsata population and the two China mainland populations, we further investigated the genetic differentiation between Hainan Island $A$. dorsata and China mainland $A$. dorsata. Results showed that they were also highly significant $\left(F_{\mathrm{ST}}=0.131 \pm 1.042, P=0.000\right)$. Allelic richness $(A)$, expected heterozygosities $(H \mathrm{~s})$, and private allelic richness (pA) were all lower in the Hainan population than the mainland population using one-way ANOVAs $\left(A, F_{1,8}=7.954, P=\right.$ $0.022 ; H \mathrm{~s}, F_{1,8}=6.360, P=0.036 ; \mathrm{pA}, F_{1,8}=$ 6.551, $P=0.034)$.

\section{DISCUSSION}

Estoup et al. (1994) compared the genetic structure within an Apis mellifera colony using derived paternal DNA microsatellites with the genetic structure of the local honeybee population and found that the genetic diversity within the colony could provide a good estimate of that of the local honeybee population. In our study, we used the genotypes of derived workers' fathers for estimating genetic diversity and population structure. This method has also been used in the genetic population structure analyses of Indian A. dorsata populations (Paar et al. 2004) and another social insect army ant, Eciton burchellii (Berghoff et al. 2008).

Microsatellites confirmed their discriminating power for population structure analysis in our study. Significant genetic differentiation was found among $A$. dorsata populations from different regions in China ( $F_{\mathrm{ST}}$ and AMOVA). The sampling regions in our study encompass

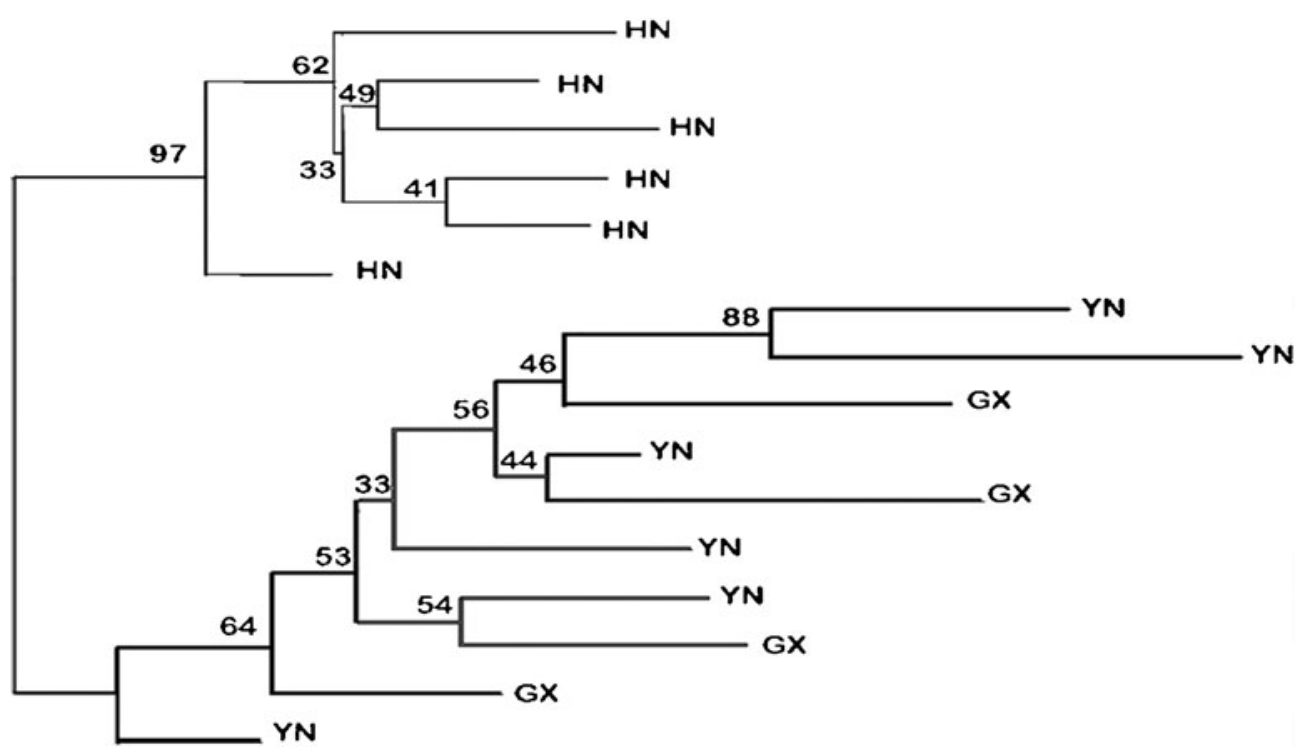

Figure 2. Neighbor-joining tree based on $\mathrm{D}_{\mathrm{A}}$ distances among 16 samples from three populations of $A$. dorsata in China. $H N$ Hainan, $Y N$ Yunnan, $G X$ Guangxi. 


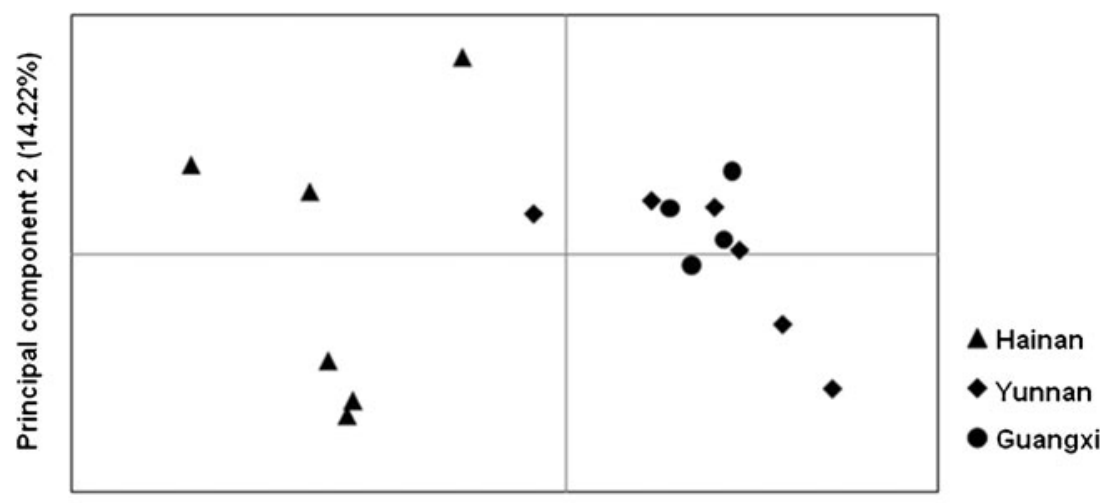

Principal component $1(55.33 \%)$

Figure 3. Principal coordinate analysis of genetic distance among 16 samples from three populations of $A$. dorsata in China.

diverse climatic zones and plant communities, which are located hundreds of kilometers apart and at different altitudes. The different climates and geographical environments may have provided ideal conditions for the divergence of $A$. dorsata in China. Significant differentiation of A. dorsata from different geographical regions was also found in northern India (Paar et. al. 2004) and Thailand (Insuan et. al. 2007).

Furthermore, we found higher pairwise $F_{\mathrm{ST}}$ scores between the Hainan Island population and each of the two mainland populations than between the two mainland populations. NJ tree and PCA analysis which based on genetic distance also revealed the significant differentiation between the Hainan Island population and the mainland populations. Qiongzhou Strait, which is located between Hainan Island and the China mainland, is about $80 \mathrm{~km}$ long and on average $30 \mathrm{~km}$ wide, and formed about 10,000 years ago in the middle Holocene (Zhao et al. 2007). The broad sea between Hainan Island and the China mainland may have been an important barrier to gene flow for $A$. dorsata and other honeybees. In a previous study which was based on mitochondrial DNA gene polymorphism (unpublished data), the Hainan Island population of $A$. dorsata was also found to be very probably diverged from the mainland populations. Based on morphological analysis and mitochondrial DNA analysis, Apis cerana from Hainan Island was also shown to be a distinct group from those of the China mainland (Yang 1984a, b; Jiang et al. 2007; Gao et al. 2008). Similarly, significant differentiation of $A$. dorsata was found between the Thailand mainland and its islands (Insuan et al. 2007).

It is noteworthy that island populations usually have lower levels of genetic variation than their equivalent continental populations (Frankham 1997; Estoup et al. 1996; Widmer et al. 1998). In our study, the Hainan Island population of $A$. dorsata also showed a lower level of genetic diversity compared to the mainland population. This indicates that the Hainan Island population of $A$. dorsata probably diverged from the mainland populations essentially by founder effects and genetic drift. The lower level of genetic diversity may also reflect recent bottlenecks in the $A$. dorsata population of Hainan Island which needs further investigations.

Our study suggests that $A$. dorsata from Hainan Island might have diverged from the China mainland and suffers genetic deterioration. Therefore, A. dorsata populations from Hainan Island and China mainland should be treated separately during the conservation of this natural resource. Considering that much of the world's threatened biodiversity exists in small island populations which are particularly susceptible to changes in habitat and disruption of system interactions (Kaiser-Bunbury et al. 
2010; Groom and Schwarz 2011), the lower level of genetic diversity in the Hainan Island population suggests that more attention should be given to Hainan Island $A$. dorsata.

\section{ACKNOWLEDGMENTS}

We gratefully acknowledge Hai-Ou Kuang, JingLin Gao, Chuan-Quan Yang, Shao-Yu He, Xue-Wen Zhang, Jie Yang, and Xuan Chen for their help during sampling. We thank De-Fang Niu and Gang Zhang for technical support and Wen-Ting Wei for statistical support. This study was supported by the fund for Modern Agro-industry Technology Research System from the Ministry of Agriculture of the People's Republic of China (CARS-45).

\section{Structure génétique de la population chinoise d'Apis dorsata, basée sur les microsatellites}

Apis dorsata / structure génétique / Chine /
microsatellites / diversité génétique

Genetische Struktur von Apis dorsata Populationen in China auf der Basis von Mikrosatelliten

Apis dorsata / genetische Struktur / China / Mikrosatelliten

\section{REFERENCES}

Arias, M.C., Sheppard, W.S. (2005) Phylogenetic relationships of honey bees (Hymenoptera: Apinae: Apini) inferred from nuclear and mitochondrial DNA sequence data. Mol. Phylogenet. Evol. 37, 25-35

Berghoff, S.M., Kronauer, D.J.C., Edwards, K.J., Franks, N.R. (2008) Dispersal and population structure of a New World predator, the army ant Eciton burchellii. J. Evol. Biol. 21, 1125-1132

Corlett, R.T. (2011) Honeybees in natural ecosystems. In: Hepburn, H.R., Radloff, S.E. (eds.) Honeybees of Asia, pp. 215-226. Springer-Verlag, Berlin

Estoup, A., Solignac, M., Harry, M., Cornuet, J.M. (1993) Characterization of $(\mathrm{GT})_{\mathrm{n}}$ and $(\mathrm{CT})_{\mathrm{n}}$ microsatellites in two insect species: Apis mellifera and Bombus terrestris. Nucleic Acids Res. 21, 1427

Estoup, A., Solignac, M., Cornuet, J.M. (1994) Precise assessment of the number of patrilines and of genetic relatedness in honeybee colonies. Proc. R. Soc. Lond. B 258, 1-7

Estoup, A., Solignac, M., Cornuet, J.M., Goudet, J., Scholl, A. (1996) Genetic differentiation of continental and island populations of Bombus terrestris (Hymenoptera: Apidae) in Europe. Mol. Ecol. 5, 19-31

Frankham, R. (1997) Do island populations have less genetic variation than mainland populations? Heredity 78, 311-327

Gao, P.F., Zhao, H.T., Zhang, C.X., Jiang, Y.S. (2008) Phylogeny of different geographic populations Apis cerana in China based on mtDNA cytochrome b gene sequences. Acta Zoologica Sinica 54, 10051013 [in Chinese]

Goldstein, D.B., Schlötterer, C. (1999) Microsatellites: evolution and applications. Oxford Univ. Press., Oxford

Goudet, J. (2001) FSTAT, a program to estimate and test gene diversities and fixation indices (version 2.9.3). Available from http://www.unil.ch/izea/softwares/ fstat.html. Updated from Goudet (1995)

Groom, S.V.C., Schwarz, M.P. (2011) Bees in the Southwest Pacific: origins, diversity and conservation. Apidologie 42(6): 759-770

Hepburn, H.R., Radloff, S.E. (2011) Biogeography. In: Hepburn, H.R., Radloff, S.E. (eds.) Honeybees of Asia, pp. 62-63. Springer-Verlag, Berlin

Insuan, S., Deowanish, S., Klinbunga, S., Sittipraneed, S., Sylvester, H.A., Wongsiri, S. (2007) Genetic differentiation of the giant honey bee (Apis dorsata) in Thailand analyzed by mitochondrial genes and microsatellites. Biochem. Genet. 45, 345-361

Jiang, Y.S., Zhao, H.T., Jiang, J.B., Cao, G.Q., Zhang, G.X., Zhu, W.J., Guo, C.J. (2007) Studies on mtDNA tRNA ${ }^{\text {leu }} \sim$ COII gene polymorphisms of Apis cerana distributed in different geographic areas in China. Scienfia Agricultura Sinica 40, 1535-1542 [in Chinese]

Kaiser-Bunbury, C.N., Traveset, A., Hansen, D.M. (2010) Conservation and restoration of plantanimal mutualisms on oceanic islands. Perspectives in Plant Ecology, Evol. Syst. 12, 131-143

Kalinowski, S.T. (2004) Counting alleles with rarefaction: Private alleles and hierarchical sampling designs. Conserv. Genet. 5, 539-543

Kalinowski, S.T. (2005) HP-RARE 1.0: a computer program for performing rarefaction on measures of allelic richness. Mol. Ecol. Notes 5, 187-189

Kraus, F.B., Koeniger, N., Tingek, S., Moritz, R.F.A. (2005) Temporal genetic structure of a drone congregation area of the giant Asian honeybee (Apis dorsata). Naturwissenschaften 92, 578-581

Kronauer, D.J.C., Berghoff, S.M., Powell, S., Denny, A.J., Edwards, K.J., Franks, N.R., Boomsma, J.J. (2006) A reassessment of the mating system characteristics of the army ant Eciton burchellii. Naturwissenschaften 93, 402-406

Lo, N., Gloag, R.S., Anderson, D.L., Oldroyd, B.P. (2010) A molecular phylogeny of the genus Apis suggests that the Giant Honey Bee of the Philippines, A. breviligula Maa, and the Plains Honey Bee 
of southern India, $A$. indica Fabricius, are valid species. Syst. Entomol. 35, 226-233

Moilanen, A., Sundström, L., Pedersen, J.S. (2004) MATESOFT: a program for deducing paternal genotypes and estimating mating system statistics in haplodiploid species. Mol. Ecol. Notes 4, 795-797

Nath, S., Roy, P., John, M., Leo, R. (1994) Honey hunters and beekeepers of Tamil Nadu. A survey document. Keystone, Pondicherry, India

Nei, M. (1987) Molecular evolutionary genetics. Columbia Univ. Press., New York

Nei M., Tajima F., Tateno Y. (1983) Accuracy of estimated phylogenetic trees from molecular data. J. Mol. Evol. 19, 153-170

Oldroyd, B.P., Nanork, P. (2009) Conservation of Asian honey bees. Apidologie 40, 296-312

Oldroyd, B.P., Wongsiri, S. (2006) Asian honey bees: biology, conservation, and human interactions. Harvard Univ. Press, Cambridge, Massachusetts

Oldroyd, B.P., Smolenski, A.J., Cornuet, J.M., Wongsiri, S., Estoup, A., Rinderer, T.E., Crozier, R.H. (1996) Levels of polyandry and intracolonial genetic relationships in Apis dorsata (Hymenoptera: Apidae). Ann. Entomol. Soc. Am. 89, 276-283

Ota T. (1993) DISPAN. Genetic distance and phylogenetic analysis. Pennsylvania State University. University Park, PA, USA

Paar, J., Oldroyd, B.P., Huettinger, E., Kastberger, G. (2002) Drifting of workers in nest aggregations of the giant honeybee Apis dorsata. Apidologie 33, 553-561

Paar, J., Oldroyd, B.P., Huettinger, E., Kastberger, G. (2004) Genetic structure of an Apis dorsata population: the significance of migration and colony aggregation. J. Hered. 95, 119-126

Partap, U. (2011) The pollination role of honeybees. In: Hepburn, H.R., Radloff, S.E. (eds.) Honeybees of Asia, pp. 227-255. Springer-Verlag, Berlin

Peakall, R., Smouse, P.E. (2006) GENALEX 6: genetic analysis in Excel. Population genetic software for teaching and research. Mol. Ecol. Notes 6, 288-295
Rousset, F. (2008) GENEPOP ' 007: a complete reimplementation of the GENEPOP software for Windows and Linux. Mol. Ecol. Resour. 8, 103-106

Ruttner, F. (1988) Biogeography and taxonomy of honeybees. Springer-Verlag, Berlin.

Sambrook, J., Fritsch, E.F., Maniatis, T. (1989) Molecular cloning: a laboratory manual. Cold Spring Harbor Laboratory Press, Cold Spring Harbor, New York

Smith, D.R. (1991) Mitochondrial DNA and honey bee biogeography. In: Smith, D.R. (eds.) Diversity in the Genus Apis, pp. 131-176. Westview Press, Boulder, $\mathrm{CO}$

Weir, B., Cockerham, C.C. (1984) Estimating F-statistics for the analysis of population structure. Evolution 38, 1358-1370

Widmer, A., Schmid-Hempel, P., Estoup, A., Scholl, A. (1998) Population genetic structure and colonization history of Bombus terrestris s.l. (Hymenoptera: Apidae) from the Canary Islands and Madeira. Heredity 81, 563-572

Wongsiri, S., Chanchao, C., Lekprayoon, C., Wattanasermkit, K., Deowanish, S., Leepitakrat, S. (2001) Honeybee diversity and management in the new millennium in Thailand. In: Proceedings of the 7th International Conference on Tropical Bees, pp. 9-14. Chiang Mai

Woyke, J., Wilde, J., Wilde, M., Sivaram, V., Cervancia, C., Nagaraja, N., Reddy, M. (2008) Comparison of defense body movements of Apis laboriosa, Apis dorsata dorsata and Apis dorsata breviligula honey bees. J. Insect Behav. 21, 481-494

Yang, G.H. (1984a) The survey of the resource of the Chinese honey bee, Zhongguo Yangfeng 3, 4-7 [in Chinese]

Yang, G.H. (1984b) The survey of the resource of the Chinese honey bee II, Zhongguo Yangfeng 6, 16-19 [in Chinese]

Zhao, H., Wang, L.R., Yuan, J.Y. (2007) Origin and time of Qiongzhou Strait. Marine Geology and Quaternary Geology 27, 33-40 [in Chinese] 